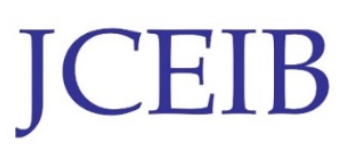

Journal Chemical Engineering and Industrial Biotechnology (JCEIB) Open Access

Volume 2 pp. 80-96; September 2017

CUniversiti Malaysia Pahang Publisher

DOI: https://doi.org/10.15282/JCEIB-V2-07.29/9/2017/2.2

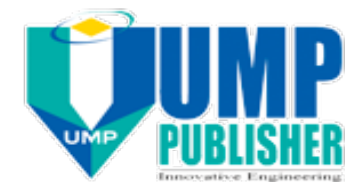

\title{
PHYTOCHEMICAL AND PHARMACOLOGICAL PROPERTIES OF Vernonia amygdalina: A REVIEW
}

\author{
Oluwaseun Ruth Alara ${ }^{a}$, Nour Hamid Abdurahman, ${ }^{\mathrm{a},}$, Siti Kholijah Abdul Mudalip ${ }^{\mathrm{a}}$, \\ Olusegun Abayomi Olalere ${ }^{\mathrm{a}}$ \\ ${ }^{a}$ Faculty of Chemical Engineering \& Natural Resources, Universiti Malaysia Pahang, Lebuhraya Tun \\ Razak, 26300, Gambang, Pahang, Malaysia \\ * Corresponding author: E-mail: abrahman@ump.edu.my \\ Tel.: +609- 5492811 Fax.: +609- 5492889
}

\begin{abstract}
Vernonia amygdalina has been a known food and medicinal plants used in Asia and Africa (West Africa) due to its pharmacological effects (antioxidant, anti-diabetes, antiinflammatory, anticancer, anti-malaria, and among others). The phytochemical studies revealed that this plant is enriched with proteins, fats, fibres, amino acids, minerals, vitamins, and carbohydrates. Many bioactive compounds had been isolated from its extracts. Therefore, this review summarized the overview of the bioactive compounds, phytochemical and pharmacological properties of $V$. amygdalina as well as its mechanism of action and toxicology.
\end{abstract}

Keywords: Bitter leaf; anti-diabetic; anti-microbial; antioxidant; toxicology.

\subsection{INTRODUCTION}

Bitter leaf (Figure 1) scientifically known as $V$. amygdalina is one of the most famous plants found in Africa and Asia. It is the most cultivated species of the genus Vernonia that is about 1,000 species of shrub (Njan et al., 2008; Agbogidi and Akpomorine, 2013; Toyang and Verpoorte, 2013; Egharevba et al., 2014). V. amygdalina has been the most prominent species in the family of Asteraceae that had been studied in Africa (Ankit et al., 2010; Nwaoguikpe, 2010; Farombi and Owoeye, 2011; Ijeh and Ejike, 2011). Normally, $V$. amygdalina does not produce seeds but its cultivation is usually done by stem planting and mostly grow in tropical areas. This plant is found majorly along the drainage, commercial plantation or forest (Yeap et al., 2010).

$V$. amygdalina is a wooded shrub of about 2 to $10 \mathrm{~m}$ height that regenerates rapidly after planted. The leaves are petiolated in shape with a bitter taste of which its name "Bitter leaf" spring up. $V$. amygdalina are being called different local names which vary from country to country (Table 1). The bitter taste had been associated with the presence of saponins, alkaloids, tannins, and glycosides. These made them act as a bittering agent and a hop substitute used for controlling microbial contamination in beer brewing without reducing the quality of malt (Ayoola et al., 2008; Ankit et al., 2010; Adama et al., 2011; Farombi and Owoeye, 2011).This plant can be harvested twice per month for the period of seven years. They are popularly used for food and traditional medicine, their characteristic odour and bitter taste can be reduced either by washing in several changes of water or by boiling before consumption (Nwaoguikpe, 2010; Agbogidi and 
Akpomorine, 2013; Toyang and Verpoorte, 2013; Alara et al., 2017a). The Medical Traditional Healer Association in Rukararwe, Uganda produced the greenish powder packed in sachet and consume as tea by patients suffering from malaria ( $\mathrm{Njan}$ et al., 2008), it has also been reported to be used in soup (Ogbono and Orugbo soups) in Nigeria and Cameron (Ndole dish) (Yeap et al., 2010; Oduah, 2012; Agbogidi and Akpomorine, 2013; Oguwike et al., 2013). The honey wine called Tei are being produced from the bitter leaf in Ethiopia (Yeap et al., 2010). The leaves and roots decoctions have been used in ethnomedicine to treat hiccups, fevers, kidney problems and stomach disorder (Igile et al., 1994; Yeap et al., 2010; Sha, 2011; Oduah, 2012).

Several studies carried out on this plant had suggested that it contains different bioactive compounds, including, flavonoids, saponins, alkaloids, tannins, phenolics, terpenes, steroidal glycosides, triterpenoids, and several types of sesquiterpene lactones (Erasto et al., 2006; Farombi and Owoeye, 2011; Kiplimo et al., 2011; Toyang and Verpoorte, 2013; Adedapo et al., 2014; Quasie et al., 2016; Luo et al., 2017). These bioactive compounds made them possess different pharmacological properties like antimicrobial, antimalarial, antithrombotic, antioxidant, anti-diabetic, laxative, hypoglycemic, antihelmintic, anti-inflammatory, cathartic, anticancer, antifertility, anti-fungi, antibacterial, and among others (Igile et al., 1994; Akinpelu, 1999; Iwalokun et al., 2006; Erasto et al., 2007; Gresham et al., 2008; Khalafalla et al., 2009; Ilondu, 2010; Farombi and Owoeye, 2011; Anibijuwon et al., 2012; Ngatu et al., 2012; Adetunji et al., 2013; Atangwho et al., 2013; Akinyele et al., 2014; Ezeadila et al., 2015; Udochukwu et al., 2015; Alara et al., 2017c).

The objective of this review paper is to outline and discuss the studies that had been done on the bioactive compounds, phytochemical and pharmacological properties of $V$. amygdalina. Besides, this review also expatiates the mechanism of action and toxicological effects of $V$. amygdalina extracts.

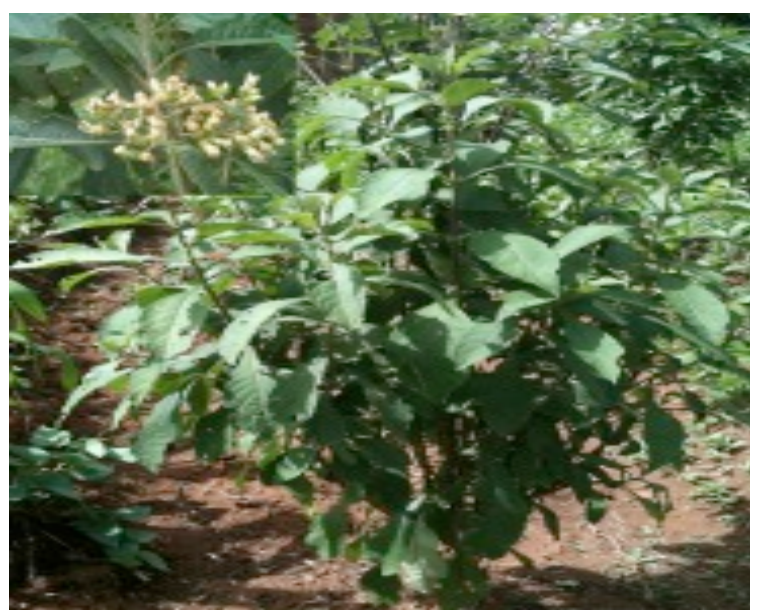

Figure 1: Vernonia amygdalina

Source: (Yeap et al., 2010) 
Table 1: Different local names of Vernonia amygdalina

\begin{tabular}{lc}
\hline Country & Local name(s) \\
\hline English & Bitter leaf \\
Nanzania & Omjunso \\
Nigeria & Onugbo, Ewuro, Etidot, \\
Ityuna, Oriw, Chusa-doki & Shiwaka \\
Malaysia & South Africa leaf \\
Rwanda & Umubilizi \\
Cameron & Suwaaka \\
Uganda & Labwori, Omubirizi, \\
Ghana & Ekibirizi \\
Congo & Awonoo, Awonwene, \\
Zimbabwe & Jankpantire \\
Gabon & Mpasi nyioso \\
China & Musikavakadzi \\
Kenya & Ndoki \\
Ethiopia & Ikaruga \\
\hline
\end{tabular}

Source: (Igile et al., 1994; Alabi et al., 2005; Iwalokun et al., 2006; Njan et al., 2008; Nwaoguikpe, 2010; Akpaso et al., 2011; Farombi and Owoeye, 2011; Owen, 2011; Oduah, 2012; Toyang and Verpoorte, 2013; Egharevba et al., 2014)

\section{Nutritional Value}

\subsection{PHYTOCHEMICAL PROPERTIES OF $V$. amygdalina}

The analysis had shown that $V$. amygdalina leaves, stems, and root is enriched with proteins, fats, fibres, amino acids, minerals vitamins, and carbohydrates (Igile et al., 1994; Alabi and Amusa, 2005; Owu et al., 2008). The nutritional compositions of $V$. amygdalina leaf, root and stems varied from one study to another, probably due to different geographical location, genetic, environmental, harvest conditions, and ecology of the plant. Early studies reported that $V$. amygdalina leaves contain carbohydrates $(4.31 \mathrm{mg} / 100 \mathrm{~g})$, proteins $(20.2 \mathrm{mg} / 100 \mathrm{~g})$, lipids $(15.0 \mathrm{mg} / 100 \mathrm{~g})$, acids $(10.26 \mathrm{mg} / 100$ $\mathrm{g})$, iodine $(35.82 \mathrm{mg} / 100 \mathrm{~g})$, hydrocyanic acid $(0.46 \mathrm{mg} / 100 \mathrm{~g})$, total oxalate $(0.62$ $\mathrm{mg} / 100 \mathrm{~g})$, amino acid, viz: thiamine $(170 \mathrm{mg} / 100 \mathrm{~g})$, pyridoxine $(2.6 \mathrm{mg} / 100 \mathrm{~g})$, ascorbic acid $(20.49 \mathrm{mg} / 100 \mathrm{~g})$, glycine $(4.63 \mathrm{mg} / 100 \mathrm{~g})$, cysteine $(1.84 \mathrm{mg} / 100 \mathrm{~g})$, casein hydrolysate $(96.99 \mathrm{mg} / 100 \mathrm{~g})$, nicotinamide $(1.65 \mathrm{mg} / 100 \mathrm{~g})$. In another study, there was a variation in the nutritional values of $V$. amygdalina leaf, stem and root as summarized in Table 2. 
Table 2: V. amygdalina leaves chemical and nutritional compositions

\begin{tabular}{|c|c|c|c|c|c|}
\hline \multicolumn{2}{|l|}{ Leaf } & \multicolumn{2}{|l|}{ Stem } & \multicolumn{2}{|l|}{ Root } \\
\hline $\begin{array}{l}\text { Composition } \\
\text { (mg/100 g dry } \\
\text { weight) }\end{array}$ & Value & $\begin{array}{l}\text { Composition per } \\
100 \text { g dry weight }\end{array}$ & Value & $\begin{array}{l}\text { Composition per } \\
100 \text { g dry weight }\end{array}$ & Value \\
\hline Sugar contents & & $\begin{array}{l}\text { Vitamins and } \\
\text { minerals }\end{array}$ & & $\begin{array}{l}\text { Vitamins and } \\
\text { minerals }\end{array}$ & \\
\hline Glucose & 7.20 & $\begin{array}{l}\text { Vitamin A } \\
(\mathrm{mg} / 100 \mathrm{~g})\end{array}$ & 21.5 & $\begin{array}{l}\text { Vitamin A } \\
(\mathrm{mg} / 100 \mathrm{~g})\end{array}$ & 30.90 \\
\hline Sucrose & 13.20 & $\begin{array}{l}\text { Vitamin C } \\
(\mathrm{mg} / 100 \mathrm{~g})\end{array}$ & 49.0 & $\begin{array}{l}\text { Vitamin C } \\
(\mathrm{mg} / 100 \mathrm{~g})\end{array}$ & 10.30 \\
\hline Fructose & 6.00 & $\begin{array}{l}\text { Vitamin } E \\
(\mathrm{mg} / 100 \mathrm{~g})\end{array}$ & 106.20 & $\begin{array}{l}\text { Vitamin E } \\
(\mathrm{mg} / 100 \mathrm{~g})\end{array}$ & 35.83 \\
\hline Lactose & 2.61 & $\begin{array}{c}\text { Thiamin (mg/100 } \\
\mathrm{g})\end{array}$ & 0.50 & $\begin{array}{c}\text { Thiamin (mg/100 } \\
\mathrm{g})\end{array}$ & 0.37 \\
\hline Galactose & 6.56 & $\begin{array}{l}\text { Riboflavin } \\
(\mathrm{mg} / 100 \mathrm{~g})\end{array}$ & 0.13 & $\begin{array}{l}\text { Riboflavin } \\
(\mathrm{mg} / 100 \mathrm{~g})\end{array}$ & 0.15 \\
\hline Arabinose & 9.25 & Niacin $(\mathrm{mg} / 100 \mathrm{~g})$ & 0.03 & $\operatorname{Niacin}(\mathrm{mg} / 100 \mathrm{~g})$ & 0.05 \\
\hline Raffinose & 5.10 & Saponins (\%) & 13.21 & Saponins (\%) & 28.52 \\
\hline Maltose & 7.24 & Alkaloid (\%) & 7.02 & Alkaloid (\%) & 6.11 \\
\hline $\begin{array}{l}\text { Mineral ash } \\
\text { and fibre } \\
\text { content }\end{array}$ & & Flavonoid (\%) & 1.02 & Flavonoid (\%) & 0.51 \\
\hline $\mathrm{Na}$ & 8.48 & $\mathrm{Fe}(\mathrm{mg} / 100 \mathrm{~g})$ & 0.12 & $\mathrm{Fe}(\mathrm{mg} / 100 \mathrm{~g})$ & 0.09 \\
\hline $\mathrm{Ca}$ & 67.39 & $\mathrm{Cu}(\mathrm{mg} / 100 \mathrm{~g})$ & 0.021 & $\mathrm{Cu}(\mathrm{mg} / 100 \mathrm{~g})$ & 0.022 \\
\hline K & 60.90 & $\mathrm{Zn}(\mathrm{mg} / 100 \mathrm{~g})$ & 0.14 & $\mathrm{Se}(\mathrm{mg} / 100 \mathrm{~g})$ & 0.016 \\
\hline $\mathrm{P}$ & 60.90 & Proximate values & & $\mathrm{Zn}(\mathrm{mg} / 100 \mathrm{~g})$ & 0.26 \\
\hline $\mathrm{Mg}$ & 88.10 & Crude fat (\%) & 34.03 & & \\
\hline & & & & Proximate values & \\
\hline $\mathrm{Mn}$ & 5.56 & Moisture (\%) & 18.50 & Crude fat $(\%)$ & 30.15 \\
\hline $\mathrm{Fe}$ & 14.20 & Crude protein $(\%)$ & 6.71 & Moisture (\%) & 12.00 \\
\hline $\mathrm{Cu}$ & 6.01 & Ash (\%) & 17.99 & Crude protein $(\%)$ & 7.30 \\
\hline $\mathrm{Zn}$ & 8.05 & - & - & Ash (\%) & 11.01 \\
\hline Ash & 10.22 & - & - & - & - \\
\hline Fibre & 9.75 & - & - & - & - \\
\hline $\begin{array}{l}\text { Vitamins and } \\
\text { amino acids }\end{array}$ & & - & - & - & - \\
\hline $\begin{array}{l}\text { Polyphenols } \\
(\mathrm{mg} / 100 \mathrm{~g})\end{array}$ & 9.75 & - & - & - & - \\
\hline $\begin{array}{l}\text { Vitamin } \\
(\mathrm{mg} / 100 \mathrm{~g})\end{array}$ & 228.40 & - & - & - & - \\
\hline $\begin{array}{l}\text { Vitamin } \\
(\mathrm{IU} / 100 \mathrm{~g})\end{array}$ & 345.50 & - & - & - & - \\
\hline $\begin{array}{l}\text { Vitamin } \\
(\mathrm{IU} / 100 \mathrm{~g})\end{array}$ & 37.30 & - & - & - & - \\
\hline
\end{tabular}




\begin{tabular}{|c|c|c|c|c|c|}
\hline $\begin{array}{l}\text { Vitamin } \quad B_{1} \\
(\%)\end{array}$ & 1.00 & - & - & - & - \\
\hline $\begin{array}{l}\text { Vitamin } \\
(\mathrm{mg} / 100 \mathrm{~g})\end{array}$ & 3.10 & - & - & - & - \\
\hline Niacin & 0.41 & - & - & - & - \\
\hline $\begin{array}{l}\text { Oxalic acid } \\
(\mathrm{mg} / 100 \mathrm{~g})\end{array}$ & 5.36 & - & - & - & - \\
\hline $\begin{array}{l}\text { Carotenoids } \\
(\mathrm{mg} / 100 \mathrm{~g})\end{array}$ & 30.00 & - & - & - & - \\
\hline $\begin{array}{l}\text { Saponins } \\
(\mathrm{mg} / 100 \mathrm{~g})\end{array}$ & 1.425 & - & - & - & - \\
\hline $\begin{array}{l}\text { Ihiamine } \\
(\mathrm{mg} / 100 \mathrm{~g})\end{array}$ & 170.00 & - & - & - & - \\
\hline $\begin{array}{l}\text { Pyrdoxine } \\
\text { (mg/100 g) }\end{array}$ & 2.06 & - & - & - & - \\
\hline $\begin{array}{l}\text { Glycine } \\
(\mathrm{mg} / 100 \mathrm{~g})\end{array}$ & 4.63 & - & - & - & - \\
\hline $\begin{array}{l}\text { Cysteine } \\
(\mathrm{mg} / 100 \mathrm{~g})\end{array}$ & 1.84 & - & - & - & - \\
\hline $\begin{array}{l}\text { Casein } \\
\text { hydrolysate } \\
(\mathrm{mg} / 100 \mathrm{~g})\end{array}$ & 96.99 & - & - & - & - \\
\hline $\begin{array}{l}\text { Nicotinamide } \\
(\mathrm{mg} / 100 \mathrm{~g})\end{array}$ & 1.65 & - & - & - & - \\
\hline $\begin{array}{l}\text { Average } \\
\text { nutritive value }\end{array}$ & 1.10 & - & - & - & - \\
\hline $\begin{array}{l}\text { Proximate } \\
\text { values }\end{array}$ & & - & - & - & - \\
\hline $\begin{array}{l}\text { Digestible } \\
\text { protein }(\mathrm{g})\end{array}$ & 16.58 & - & - & - & - \\
\hline Moisture (\%) & 79.92 & - & - & - & - \\
\hline $\begin{array}{l}\text { Crude protein } \\
(\mathrm{g})\end{array}$ & 19.23 & - & & - & - \\
\hline $\begin{array}{l}\text { Total } \\
\text { carbohydrate } \\
\text { (g) }\end{array}$ & 68.35 & - & - & - & - \\
\hline Total lipids & 4.70 & - & - & - & - \\
\hline $\begin{array}{l}\text { Reducing } \\
\text { sugar }(g)\end{array}$ & 14.31 & - & - & - & - \\
\hline $\begin{array}{l}\text { Dry matter } \\
(\%)\end{array}$ & 20.08 & - & - & - & - \\
\hline $\operatorname{Ash}(g)$ & 7.72 & - & - & - & - \\
\hline $\begin{array}{l}\text { Dietary fibre } \\
(\mathrm{g})\end{array}$ & 25.47 & - & - & - & - \\
\hline Energy (Kcal) & 392.67 & - & - & - & - \\
\hline $\begin{array}{l}\text { Total oxalate } \\
(\mathrm{mg} / 100 \mathrm{~g})\end{array}$ & 0.62 & - & - & - & - \\
\hline Iodine & 35.82 & - & - & - & - \\
\hline
\end{tabular}


$(\mathrm{mg} / 100 \mathrm{~g})$

Source: (Alabi and Amusa, 2005; Alabi et al., 2005; Nwaoguikpe, 2010; Eyong et al., 2011; Toyang and Verpoorte, 2013)

\section{Bioactive Compounds in Vernonia amygdalina}

Several studies had been done in isolating and characterizing some bioactive compounds from $V$. amygdalina. The phytochemical studies had resulted in the isolation of flavonoids, saponins, alkaloids, tannins, phenolics, terpenes, steroidal glycosides, triterpenoids, and several types of sesquiterpene lactones (Erasto et al., 2006; Farombi and Owoeye, 2011; Kiplimo et al., 2011; Toyang and Verpoorte, 2013; Adedapo et al., 2014; Quasie et al., 2016; Luo et al., 2017). Figure 2 shows some of the isolated bioactive compounds reported in the literature. Sesquiterpene lactones (vernodalinol, vernolepin, vernomygdin, hydroxyvernolide, vernolide and vernodalol) had been reported to inhibit breast cancer cell growth, possessed antitumoral and antimicrobial properties, and exhibited a significant bactericidal activity against gram bacteria (Jisaka et al., 1993; Erasto et al., 2006; Amodu et al., 2013; Luo et al., 2017). Isolated vernoniosides from $V$. amygdalina leaves exhibited anti-inflammatory property and used in the treatment of gastrointestinal disorder when tested with murine macrophage cell line and wild chimpanzees, respectively (Huffman et al., 1993; Quasie et al., 2016). Flavonoids, tannins, saponins, and triterpenoids had been studied to possess antioxidant and hypolipidaemic effects (Igile et al., 1994; Erasto et al., 2007; Ayoola et al., 2008; Farombi and Owoeye, 2011; Atangwho et al., 2013; Alara et al., 2017b).<smiles>O=c1cc(-c2ccc(O)c(O)c2)oc2cc(O)cc(O)c12</smiles>

Luteolin

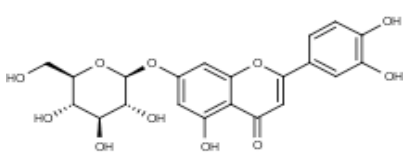

Luteolin 7-O- $\beta$-glucoside<smiles>O=C(O)C1OC(Oc2cc(O)c3c(c2)OC(c2ccc(O)c(O)c2)CC3O)C(O)C(O)C1O</smiles>

Luteolin7-O-glucuronide

(a)

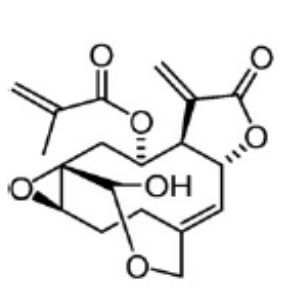

Vernolide<smiles>C=CC12COC(=O)C(=C)[C@H]1[C@@H](C(=C)C(=O)O)[C@H]([C@@H](C)OC(=O)C(=C)CO)C[C@H]2C</smiles>

Vernodalol<smiles>C=C[C@]12COC(=O)C(=C)[C@H]1[C@@H]1OC(=O)C(=C)[C@H]1[C@@H]2O</smiles>

Vernolepin

Vernomygdin

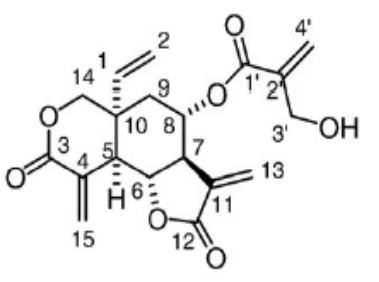

Vernodalin<smiles>C=C[C@]12COC(=O)C(=C)[C@]1(C=C)[C@@H](O)[C@@H]1C(=C)C(=O)O[C@H]1C2</smiles>

Vernomenin

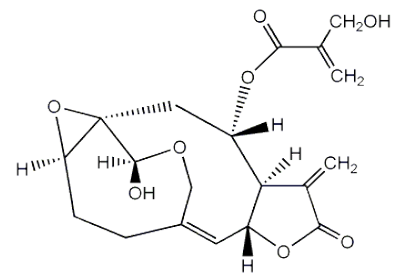

Hydroxyvernolide

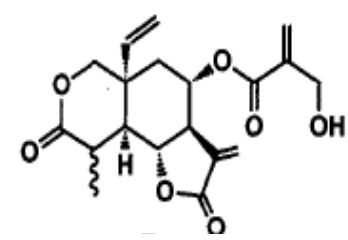

4,15-dihydrovernodalin 

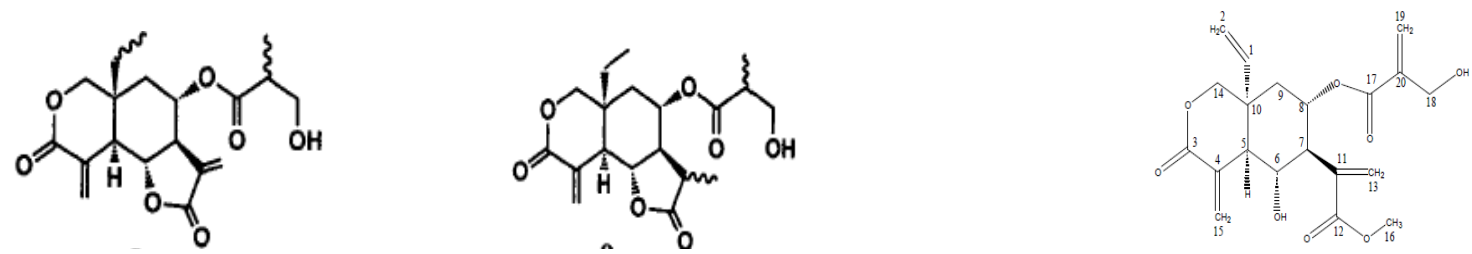

$1,2,2^{\prime}, 3^{\prime}$-tetrahydrovernodalin $1,2,11,12^{\prime}, 3^{\prime}$-hexahydrovernodalin Epiverodalol
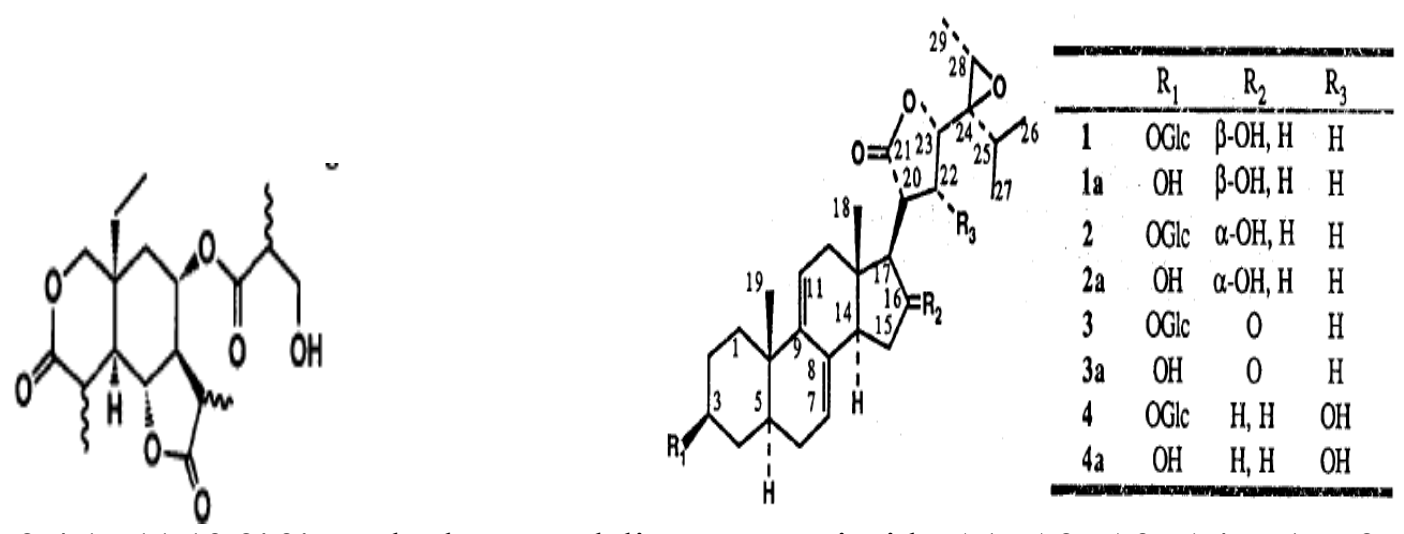

1,2,4,15,11,13,2',3'-octahydrovernodalin Vernonioside A1, A2, A3, A4, B1, B2, B3, and B4<smiles></smiles>

Thiamin<smiles>N[C@@H](CS)C(=O)O</smiles>

Cysteine<smiles>O=C1O[C@H](CO)[C@H](O)C1O</smiles>

Ascorbic acid<smiles>Cc1ncc(CO)c(CO)c1O</smiles>

Pyridoxine<smiles>NCC(=O)O</smiles>

Glycine

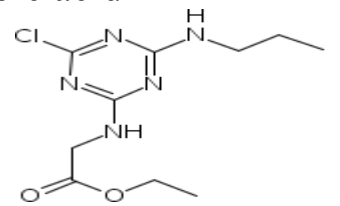

(c)

Figure 2: Isolated flavonoids (a), sesquiterpenes lactones (b) and triterpenes (c) from $V$. amygdalina (Erasto et al., 2006; Farombi and Owoeye, 2011; Kiplimo et al., 2011; Toyang and Verpoorte, 2013; Adedapo et al., 2014; Quasie et al., 2016; Luo et al., 2017)

\section{Flavonoids}

Flavonoids are a group of natural compounds found in plants with variable phenolic structures. They are present virtually in all parts of the plant. Flavonoids are responsible for the taste, colour, protection of vitamins and enzymes, and prevention of fat oxidation (Yao et al., 2004). The pharmacology importance of flavonoids, including, antioxidant, hepatoprotective, antibacterial, anti-inflammatory, anticancer, and antiviral activities are indispensable in the human body (Yao et al., 2004; Shashank and Abhay, 2013). V. amygdalina possesses flavonoids which can be extracted from the leaves using organic solvents. Different flavonoids had been isolated from the crude extracts of $V$. amygdalina leaf. In the early study, three flavones (luteolin, luteolin 7-O- $\beta$ glucuronoside and lutelin7-O- $\beta$-glucoside) were identified (Figure $2 \mathrm{a}$ ). The identified flavones showed strong antioxidant activities (Igile et al., 1994). Luteolin exhibited stronger antioxidant activity in comparison to the synthetic butylated hydroxytoluene 
(BHT) at $15 \mathrm{mg} / \mathrm{l}$. Besides this, luteolin 7-O-glucuronoside (the most abundant compound) and luteolin 7-O-glucoside also possess similar antioxidant activity but significantly lower as compared to luteolin. This may be attributed to the blockage of glycosides with glucose or uronic acid linked at the 7-O position compared with the unsubstituted 5,7- $\mathrm{OH}$ of luteolin. Higher antioxidant inhibition was observed in the ethanolic extraction of luteolin than aqueous extract (Yeap et al., 2010). This may contribute to the higher antioxidant activity of ethanol extract compared to water extract. The chemical structures of the isolated flavones are shown in Figure 2a.

\section{Sesquiterpene lactones}

This is another group of phytochemicals isolated from $V$. amygdalina. Sesquiterpenes lactones are secondary metabolites widely found in family Asteraceae. They possess pharmacology properties like antibacterial, anaesthetic, antifungal, anti-inflammatory, antiprotozoal, and antimicrobial. Most of the isolated sesquiterpene lactones from $V$. amygdalina were from leaf, stem, and root. The isolated compounds were vernolide, vernolepin, vernodalin, hydroxyvernolide, vernodalol, vernomygdin, vernomenin, 4,15dihydrovernodalin, 1,2,11,12',3' hexahydrovernodalin, 1,2,4,15,11,13,2',3' octahydrover nodalin, epivernodalol, and vernonioside A1, A2, A3, A4, B1, B2, B3, and B4 (Huffman et al., 1993; Jisaka et al., 1993; Khalafalla et al., 2009; Owoeye et al., 2010; Quasie et al., 2016; Luo et al., 2017). The chemical structures of these sesquiterpenes lactones are showed in Figure $2 \mathrm{~b}$.

Vernodalin and vernolide had been reported to exhibit potent activity $\left(\mathrm{IC}_{50}\right.$ for P-388 and L-121O cells: 0.11 and $0.17 \mu \mathrm{g} / \mathrm{ml}$ for vernodalin and 0.13 and $0.11 \mu \mathrm{g} / \mathrm{ml}$ for vernolide, respectively), while the activity of hydroxyvernolide and vernodalol was weak. The lower activity of hydroxyvernolide, vernolepin and vernodalol could be explained by the loss of hydrophobicity in the acyl moiety (Jisaka et al., 1993). In another study, vernolide showed a significant inhibition against gram-positive bacteria B. cereus, Staphylococcus epidermidus, B. subtilis, S. aureus, M. luteus, M. kristinae, and Streptococcus pyrogens and the gram-negative bacterium Salmonella pooni. These showed its antibacterial activity (Erasto et al., 2006; Luo et al., 2017). More so, vernodalin and vernomygdin had been reported to possess antitumor activity against human nasopharynx carcinoma KB, L-1210 cancer cell lines and P-388 leukaemia mouse.

The antifeedant activity was noticed from the isolated 11,13-dihydrovernorodeline, this can resist insects from feeding on the plant but does not result in lethality (Yeap et al., 2010). Vernolepin had also been reported to show antiplatelet property against ADP, arachidonic acid and collagen-induced platelet aggregation in rabbits (Erasto et al., 2006; Yeap et al., 2010). Similar to other isolated sesquiterpenes lactones, vernomenin inhibited L-1210 cancer cell lines and P-388 leukaemia mouse (Jisaka et al., 1993; Yeap et al., 2010).

\section{Triterpenoids}

Triterpenoids are widely distributed in medicinal and edible plants. This phytochemical group is being evaluated for use in new functional foods, cosmetics, foods, and healthcare products. They have been isolated from the leaf, root and stem of $V$. amygdalina. They possess diverse pharmacological properties including anticancer, anti-inflammatory, hepatoprotective, antioxidant, antibacterial, antileukaemia, analgesic 
and anti-nociceptive (Igile et al., 1994; Alabi et al., 2005; Nwaoguikpe, 2010; Yeap et al., 2010; Wong et al., 2013). Some of the isolated triterpenes are thiamine, ascorbic acid, pyridoxine, glycine, cysteine, casein hydrolysate, eucalyptol, beta piene, myrtenal, and alpha-muurolol (Figure 2c).

\subsection{PHARMACOLOGICAL EFFECTS OF $V$. amygdalina}

$V$. amygdalina had been reported to possess several pharmacological effects like antimicrobial, antimalarial, antithrombotic, antioxidant, anti-diabetic, laxative, hypoglycemic, antihelmintic, anti-inflammatory, cathartic, anticancer, antifertility, antifungi, antibacterial, and among others (Igile et al., 1994; Akinpelu, 1999; Iwalokun et al., 2006; Erasto et al., 2007; Gresham et al., 2008; Khalafalla et al., 2009; Ilondu, 2010; Farombi and Owoeye, 2011; Anibijuwon et al., 2012; Ngatu et al., 2012; Adetunji et al., 2013; Atangwho et al., 2013; Akinyele et al., 2014; Ezeadila et al., 2015; Udochukwu et al., 2015; Alara et al., 2017c).

\section{Antioxidant Effect}

The crude extracts from $V$. amygdalina had been studied to possess an antioxidant property by scavenging the free radicals cells. The aqueous extracts from the leaf showed a significant reduction in the malondialdehyde levels of oxidative stressed streptozotocin-induced diabetic rats (Nwanjo, 2005). The leaves extracts had been examined to scavenge $75-99.3 \%$ DPPH radicals and $96.2-100 \%$ of the ABTS radicals (Erasto et al., 2007). The presence of flavonoids in the $V$. amygdalina extracts had been attributed to their antioxidant property (Igile et al., 1994; Ayoola et al., 2008; Farombi and Owoeye, 2011). In vivo biochemical analysis of $V$. amygdalina leaf extracts on the rats showed an appreciable increase in the level of the antioxidants, superoxide dismutase, catalase, glutathione, and malondialdehyde. In addition, daily administration of the extracts to rats resulted in the reduction of their lipid profile when compared to the control (Imaga and Bamigbetan, 2013). The chemopreventive effects of $V$. amygdalina extracts had been attributed to their ability to scavenge free radical cells, interfere with DNA binding of some transcription factors, and induced detoxification (Amodu et al., 2013). Moreover, the extracts from this plant had been found to inhibit bleaching B-carotene, lipid peroxidation induced by iron ion ascorbate in a rat liver microsomal preparation, and linoleic acid (Khalafalla et al., 2009; Yeap et al., 2010).

\section{Anti-diabetic Effect}

Diabetes mellitus has been associated with a fasting venous plasma glucose concentration higher than $7.8 \mathrm{mmol} / 1(140 \mathrm{mg} / \mathrm{dl}) 2 \mathrm{~h}$ after an oral ingestion of $75 \mathrm{~g}$ glucose equivalent or carbohydrate meal (Nwanjo, 2005; Letchuman et al., 2010; Jan Mohamed et al., 2015). Studies had shown that aqueous extracts from $V$. amygdalina leaves reduced the blood glucose, increased the serum triglyceride levels and serum MDA, increased the LDL-cholesterol, and normalized cholesterol concentrations in streptozocin-induced diabetic rats (Nwanjo, 2005). In another study on the effect of $V$. amygdalina leaf extracts on blood glucose of diabetic rats, the results showed that decrease in blood glucose after administration of the extracts may be associated with the presence phytochemicals, vitamins and other nutrients in the extracts (Osinubi, 2008; Nwaoguikpe, 2010; Ejike et al., 2013). The aqueous extracts had been administered to alloxan-diabetic rats, the blood glucose and serum triglyceride levels were significantly reduced (Akah et al., 2004). Justin et al. 2012 had reported that decoction of $V$, amygdalina and Azadirachta indica leaves promptly lowered blood glucose and 
maintained a relatively steady level over the study period. Likewise, the study on the activities of $V$. amygdalina leaves aqueous extracts on the haemostatic, haematological and biochemical profile of induced male diabetic albino rats showed a significant reduction in the glucose level (Oguwike et al., 2013).

\section{Anti-allergic Effect}

The extracts from $V$. amygdalina leaves had been reported to inhibit and prevent atopic or eczema dermatitis syndrome in mice (Ngatu et al., 2012).

\section{Anti-inflammatory Effect}

$V$. amygdalina leaves extracts had been reported to possess anti-inflammatory activity when applied to the ear of rat suffering from inflammation. It produced a significant reduction when compared with the application of acetylsalicylic acid (Georgewill and Georgewill, 2010). The percentage of inhibition of leaves extracts was higher than roots extracts (Egharevba et al., 2014).

\section{Anticancer Effect}

Breast cancer has been the second leading cause of deaths of women in the world (American Cancer Society, 2016). V. amygdalina leaves extracts had been reported to inhibit the proliferation of MCF-7 and MDA-MB-231 which involved the stimulation of cell-type specific G1/S phase cell cycle arrest in only MCF-7 cells but not in MDAMB-231 cells given an approximate of $70 \%$ of diagnosed breast cancer express ER- $\alpha$ (Opata and Izevbigie, 2006; Gresham et al., 2008; Wong et al., 2013). Owoeye et al. 2010 had also reported the presence of epivernodalol in the methanolic extract of $V$. amygdalina leaf which was active against HT-144 (skin melanoma) cell line. On the other hand, the aqueous extracts were administered to mice for 4 weeks at dose 10 to $100 \mu \mathrm{g} / \mathrm{ml}$ per day, there was a significant reduction in $\mathrm{CYP}_{1} \mathrm{~A}_{2}$ expression. Methanol and chloroform extracts were as well inhibited human leukaemia monocyte THP-1 cell line with $\mathrm{IC}_{50}$ values of 19.1 and $243.4 \mu \mathrm{g} / \mathrm{ml}$, respectively (Yeap et al., 2010).

\section{Antimicrobial Effect}

The aqueous and ethanol extracts of $V$. amygdalina leaves had shown antimicrobial effects against Staphylococcus aureus, Escherichia coli, Pseudomonas aeruginosa, Klebsiella spp., and Candida albicans with the MIC values ranged between 12.5 and 50 $\mathrm{mg} / \mathrm{ml}$ (Ghamba et al., 2014). In another study, ethanolic and aqueous extracts of $V$. amygdalina leaves had shown a higher value of MIC inhibitions on Streptococcus mutans at 25 and $55 \mathrm{mg} / \mathrm{ml}$, respectively (Akinpelu, 1999; Anibijuwon et al., 2012).

\section{Anti-malaria Effect}

Leaves and roots of $V$. amygdalina extract possessed antimalarial effect against drug sensitive Plasmodium berghei in mice which resulted in $67 \%$ and $53.5 \%$ suppression of parasitaemia after the four days of administration, respectively (Audu et al., 2012). The leaves extracts had exhibited a significant antiplasmodial effect in mice against Plasmodium berghei with $73 \%$ inhibition (Njan et al., 2008). In the same vein, isolated sesquiterpene lactones from $V$. amygdalina had been reported to show antiplasmodial property with $\mathrm{IC}_{50}<4 \mu \mathrm{g} / \mathrm{ml}$ against Plasmodium falciparum (Egharevba et al., 2014). $V$. amygdalina leaf extracts dose had dependently restored the efficacy of chloroquine against Plasmodium berghei in mice which had developed resistance (Iwalokun, 2008). 
Significant results were obtained antiplasmodial effects of ethanolic and aqueous extracts at $\mathrm{IC}_{50}$ values 44.03 and $41.690 \mu \mathrm{g} / \mathrm{ml}$, respectively (Egharevba et al., 2014).

\section{Antifertility Effect}

The antifertility effect of $95 \%$ ethanolic extracts of $V$. amygdalina leaves on the isolated mouse uterus had been reported at doses of $0.385,0.5$, and $1.0 \mathrm{~g} / \mathrm{kg}$ body weight of mice when compared with the control agonist acetylcholine $(1 \mathrm{~g} / \mathrm{kg})$. Significant reduction in a mean number of implantation sites, the number of live foetuses and survival percentage were recorded (Egharevba et al., 2014).

\section{Antifungal Effect}

Sesquiterpene lactones had been known to be highly antifungal (Barrero et al., 2000; Wedge et al., 2000). The presence of vernodalol and vernolide which belongs to sesquiterpene lactones in the $V$. amygdalina leaves extracts made them exhibit higher antifungal effect against Penicillium notatum and Aspergillus flavus with $\mathrm{LC}_{50}$ values of $0.4 \mathrm{mg} / \mathrm{ml}$ each (Erasto et al., 2006).

\section{Antibacterial Effect}

Sesquiterpene lactones from $V$. amygdalina leaves had exhibited antibacterial against five gram-positive bacteria with the MIC value of $0.25 \mathrm{mg} / \mathrm{ml}$, but lack efficacy against gram-negative bacteria (Erasto et al., 2006). Likewise, the ethanolic stem extracts inhibited antibacterial effect against Staphylococcus aureus with $50 \mathrm{mg} / \mathrm{ml}$ concentration (Akinyele et al., 2014). The aqueous, ethanolic and methanolic extracts of the leaves had been reported to exhibit strong potency against clinical bacteria: Pseudomonas aeruginosa, Staphylococcus aureus and Escherichia coli (Alo et al., 2012; Adetunji et al., 2013).

\section{Anti-leukaemia Effect}

The root culture of cold water, hot water, and ethanolic $V$. amygdalina extracts had been tested on the patients suffering from acute leukaemia and myeloid leukaemia. The extracts showed a higher level of anti-leukemia activity on the patients (Khalafalla et al., 2009).

\subsection{MECHANISM OF ACTIONS OF $V$. amygdalina EXTRACTS}

$V$. amygdalina leaves extracts had been reported to possess protective effect against carbon tetrachloride-induced hepatotoxicity by the antioxidant mechanism of action (Adesanoye and Farombi, 2010). Whereas, the administration of $V$. amygdalina aqueous extracts to wistar rats showed a dose-dependent improvement on CD4+ cells in comparison to control group. It was suggested that the mechanism could be related to the presence of antioxidant bioactive compounds (saponins, tannins, and flavonoids). Another possible mechanism of action could be due to early maturation and release of leucocytes (Momoh et al., 2010). Therefore, the used of $V$. amygdalina leaf aqueous extracts were suggested as an immune booster in related health conditions (Egharevba et al., 2014).

\subsection{TOXICOLOGY OF $V$. amygdalina}

The toxicology of $V$. amygdalina leaves extracts had been studied on mice and the results showed no clinical signs of toxicity or toxicological effects in the treated groups, except for a significant decrease in red blood cell count and a dose-dependent increase 
in serum bilirubin (Njan et al., 2008). Owen et al. 2011 had also reported that there was no indication of toxicity in the $V$. amygdalina leaves extracts upon biomolecules evaluations when administered to broiler finisher chickens. Likewise, there was no appreciable difference in the glucose level, haematological profile, liver, and kidney function of the tested rats when the extracts were administered to rats (Imaga and Bamigbetan, 2013). Egharevba et al. (2014) reported that the toxicity limit was insignificant when compared with the highly toxic substances (toxicity at less than 1 $\mathrm{mg} / \mathrm{kg}$ ). Studies on the acute toxicity of the leaf extracts resulted in $\mathrm{LD}_{50}$ of $5.1523 \mathrm{~g} / \mathrm{kg}$ when administered orally and this showed that the extracts were non-toxic (Adiukwu et al., 2012). In contrary, Temma people of Sierra Leone called bitter leaf as 'goat killer', this makes the animals to stay away from it due to its bitterness (Yeap et al., 2010). Table 3 shows some of the in vivo and in vitro toxicity of $V$. amygdalina.

Table 3: In vivo and in vitro toxicology of Vernonia amygdalina

\begin{tabular}{|c|c|c|c|c|c|}
\hline Animal & $\begin{array}{l}\text { Type of } \\
\text { extract }\end{array}$ & $\begin{array}{c}\mathrm{LD}_{50}(\mathrm{mg} / \mathrm{kg} \\
\text { b.w.) }\end{array}$ & $\begin{array}{c}\text { Mode of } \\
\text { administration }\end{array}$ & Consequences & Reference(s) \\
\hline Rabbit & Aqueous & 1122 & $\begin{array}{l}\text { Intra-peritoneal } \\
\text { injection }\end{array}$ & - & $\begin{array}{c}\text { Akah and } \\
\text { Okafor } \\
(2006)\end{array}$ \\
\hline \multirow[t]{6}{*}{ Rat } & $\begin{array}{l}\text { Methanol } \\
\text { leaf } \\
\text { extract } \\
\text { (28 days } \\
\text { at } \\
\text { doses of } \\
80, \\
160 \text { and } \\
320\end{array}$ & - & $\begin{array}{l}\text { Intravenous } \\
\text { injection }\end{array}$ & $\begin{array}{c}\text { The } \\
\text { histopathologic } \\
\text { al studies } \\
\text { showed no } \\
\text { significant } \\
\text { abnormalities } \\
\text { in all the vital } \\
\text { organs of the } \\
\text { rats. }\end{array}$ & $\begin{array}{l}\text { Akah et al. } \\
\text { (2009) }\end{array}$ \\
\hline & $\mathrm{mg} / \mathrm{kg})$ & & $\begin{array}{l}\text { Intra-peritoneal } \\
\text { injection }\end{array}$ & $\begin{array}{l}\text { No effect on } \\
\text { glycolysis }\end{array}$ & $\begin{array}{c}\text { Atangwho et } \\
\text { al. (2014) }\end{array}$ \\
\hline & $\begin{array}{c}\text { Chlorofor } \\
\mathrm{m}\end{array}$ & - & & & \\
\hline & $\begin{array}{c}\text { fraction } \\
(7-14 \\
\text { days at } 55 \\
\mathrm{mg} / \mathrm{kg} \\
\text { b.w.) }\end{array}$ & & $\begin{array}{l}\text { Intra-peritoneal } \\
\text { injection }\end{array}$ & - & $\begin{array}{l}\text { Asante et al. } \\
\text { (2016) }\end{array}$ \\
\hline & $\begin{array}{c}\text { Ethanol } \\
\text { (dosage at } \\
40 \\
\mathrm{mg} / \mathrm{kg} \text { ) }\end{array}$ & - & Oral & $\begin{array}{l}\text { Any apparent } \\
\text { toxic symptom } \\
\text { or mortality } \\
\text { was not } \\
\text { observed after } \\
\text { the } 24 \mathrm{~h}\end{array}$ & $\begin{array}{c}\text { Mansurah et } \\
\text { al. (2013) }\end{array}$ \\
\hline & $\begin{array}{c}\text { Aqueous } \\
\text { of } \\
\text { combined } \\
V .\end{array}$ & & & & \\
\hline
\end{tabular}




\begin{tabular}{|c|c|c|c|c|c|}
\hline & $\begin{array}{c}\text { amygdali } \\
\text { na and } O . \\
\text { gratissim } \\
\text { um }(24 \mathrm{~h} \\
\text { at doses } \\
\text { from } 10- \\
5000 \\
\mathrm{mg} / \mathrm{kg})\end{array}$ & & & & \\
\hline $\begin{array}{l}\text { Broiler } \\
\text { finishers' }\end{array}$ & $\begin{array}{c}\text { Leaf meal } \\
\text { (28 days } \\
\text { using } 0 \% \text {, } \\
5 \%, 10 \% \\
\text { and } 15 \% \\
\text { VALM) }\end{array}$ & - & $\begin{array}{c}\text { Mixed with } \\
\text { broilers' meals }\end{array}$ & $\begin{array}{l}\text { The leaf meals } \\
\text { have no } \\
\text { adverse effect } \\
\text { on the kidney, } \\
\text { since the } \\
\text { creatinine } \\
\text { levels were not } \\
\text { significantly } \\
\text { altered. }\end{array}$ & Owen (2011) \\
\hline $\begin{array}{l}\text { Murine } \\
\text { macrophages } \\
\text { J774 }\end{array}$ & $\begin{array}{l}\text { Lipophili } \\
\text { c extract }\end{array}$ & $\begin{array}{c}\mathrm{IC}_{50} \text { value of } \\
6.48 \mu \mathrm{g} / \mathrm{ml}\end{array}$ & - & - & $\begin{array}{c}\text { Ganfon et al. } \\
\text { (2008) }\end{array}$ \\
\hline Guinea pig & $\begin{array}{l}\text { Aqueous } \\
(0.3 \\
\mathrm{mg} / \mathrm{ml})\end{array}$ & Injection & - & $\begin{array}{l}\text { Increase of } \\
\text { uterine, } \\
\text { intestine and } \\
\text { jejunum } \\
\text { contraction } \\
\text { which } \\
\text { sustained for } \\
30 \text { min with } \\
\text { elevated } \\
\text { concentrations } \\
\text { used }\end{array}$ & $\begin{array}{l}\text { Yeap et al. } \\
\text { (2010) }\end{array}$ \\
\hline Albino mice & $\begin{array}{c}\text { Aqueous } \\
\text { (7 days at } \\
\text { doses of } \\
125 \\
\mathrm{mg} / \mathrm{kg} \text { ) }\end{array}$ & - & $\begin{array}{l}\text { Intra-peritoneal } \\
\text { injection }\end{array}$ & $\begin{array}{c}\text { Increase of } \\
\text { serum enzyme } \\
\text { markers level } \\
\text { was more } \\
\text { severe when it } \\
\text { was } \\
\text { consumed with } \\
\text { antimalarial } \\
\text { drug } \\
\text { chloroquine }\end{array}$ & $\begin{array}{l}\text { Iwalokun } \\
(2008)\end{array}$ \\
\hline
\end{tabular}

\subsection{CONCLUSION}

This review reveals that $V$. amygdalina is endowed with different bioactive compounds that possess several pharmacological properties. Its medicinal potential has been explored, proven very effective with no toxicity to health. $V$. amygdalina is an ethnomedicinal plant that may be used in managing tropical diseases. However, other 
pharmacological properties of this plant abound which can require genetic evaluation. In addition, several works had been carried out on the phytochemical, pharmacological properties, toxicology and mechanism of action of $V$. amygdalina leaf but few studies had been done on the stems and roots. Therefore, further studies are required to isolate and validate the potential of the $V$. amygdalina stems and roots.

\section{ACKNOWLEDGEMENT}

The authors acknowledge the financial contribution of Universiti Malaysia Pahang under the UMP grant (RDU160325).

\section{REFERENCES}

Adama, K. K., Oberafo, A. A. and Dika, S. (2011). Bitterleaf as Local Substitute for Hops in the Nigerian Brewing Industry. Scholars Research Library. 3(4): 388-397.

Adedapo, A. A., Aremu, O. J. and Oyagbemi, A. A. (2014). Anti-oxidant, Anti-inflammatory and Antinociceptive Properties of the Acetone Leaf Extract of Vernonia amygdalina in Some Laboratory Animals. Advanced Pharmaceutical Bulletin. 4: 591-598.

Adesanoye, O. A. and Farombi, E. O. (2010). Hepatoprotective Effects of Vernonia amygdalina (Astereaceae) in Rats Treated with Carbon Tetrachloride. Experimental and Toxicologic Pathology. 62(2): 197-206.

Adetunji, C. O., Olaniyi, O. O. and Ogunkunle, A. T. J. (2013). Bacterial Activity of Crude Extracts of Vernonia amygdalina on Clinical Isolates. Journal of Microbiology and Antimicrobials. 5(6): 6064.

Adiukwu, P., Amon, A., Nambatya, G., Adzu, B., Imanirampa, L., Twinomujuni, S. and Katusiime, B. (2012). Acute Toxicity, Antipyretic and Antinociceptive Study of the Crude Saponin from an Edible Vegetable: Vernonia amygdalina leaf. International Journal of Biological and Chemical Sciences. 6(3): 1019-1028.

Agbogidi, O. M. and Akpomorine, M. (2013). Health and Nutritional Benefits of Bitterleaf (Vernonia amygdalina Del.). International Journal of Applied Pharmaceutical Sciences and Biological Sciences. 2(3): 164-170.

Akah, P., Njoku, O., Nwanguma, A. and Akunyili, D. (2004). Effects of Aqueous Leaf Extract of Vernonia amygdalina on Blood Glucose and Triglyceride Levels of Alloxan-Induced Diabetic Rats (Rattus rattus). Animal Research International. 1: 90-94.

Akah, P. A., Alemji, J. A., Salawu, O. A., Okoye, T. C. and Offiah, N. V. (2009). Effects of Vernonia amygdalina on Biochemical and Hematological Parameters in Diabetic Rats. Asian Journal of Medical Sciences. 1(3): 108-113.

Akinpelu, D. A. (1999). Antimicrobial Activity of Vernonia amygdalina leaves. Fitoterapia. 70(4): 432434.

Akinyele, B. J., Oladejo, B. O., Akinyemi, A. I. and Ezem, L. O. (2014). Comparative Study of the Antibacterial Effect of Mouth Washes and Vernonia amygdalina (Del.) on Some Tooth Decay Causing Bacteria. British Microbiology Research Journal. 4(7): 749-758.

Akpaso, M. I., Atangwho, I. J., Akpantah, A., Fischer, V. A., Igiri, A. O. and Ebong, P. E. (2011). Effect of Combined Leaf Extracts of Vernonia amygdalina (Bitter Leaf) and Gongronema latifolium (Utazi) on the Pancreatic $\beta$-Cells of Streptozotocin-Induced Diabetic Rats. British Journal of Medicine \& Medical Research. 1(11): 24-34.

Alabi, D. A. and Amusa, N. A. (2005). Chemicals and Nutritional Composition of Four Botanicals with Fungitoxic Properties. World Journal of Agricultural Sciences. 1(1): 84-88.

Alabi, D. A., Oyero, I. A. and Amusa, N. A. (2005). Fungitoxic and Phytotoxic Effect of Vernonia amygdalina (L), Bryophyllum pinnantus Kurz, Ocimum gratissimum (Closium) L. and Eucalyptna globules (Caliptos) Labill Water Extracts on Cowpea and Cowpea Seedling Pathogens in AgoIwoye, South Western Nigeria. World Journal of Agricultural Sciences. 1(1): 70-75.

Alara, O. R., Abdurahman, N. H. and Olalere, O. A. (2017a). Mathematical Modelling and Morphological Properties of Thin Layer Oven Drying of Vernonia amygdalina Leaves. Journal of the Saudi Society of Agricultural Sciences.

Alara, O. R., Abdurahman, N. H., Abdul Mudalip, S. K. and Olalere, O. A. (2017b). Effect of Drying Methods on Free Radicals Scavenging Activity of Vernonia amygdalina growing in Malaysia. Journal of King Saud University - Science. 
Alara, O. R., Abdurahman, N. H. and Olalere, O. A. (2017c). Ethanolic Extraction of Flavonoids, Phenolics and Antioxidants from Vernonia amygdalina Leaf using Two-Level Factorial Design. Journal of King Saud University - Science.

Alo, M. N., Anyim, C., Igwe, J. C., Elom, M. and Uchenna, D. S. (2012). Antibacterial Activity of Water, Ethanol and Methanol Extracts of Ocimum gratissimum, Vernonia amygdalina and Aframomum melegueta. Pelagia Research Library. 3(2): 844-848.

American Cancer Society. (2016). Cancer Facts \& Figures 2016. Cancer Facts \& Figures 2016, pp. 1-72.

Amodu, A., Itodo, S. E. and Musa, D. E. (2013). Nigerian Foodstuffs with Tumour Chemosuppressive Polyphenols. International Journal of Pharmaceutical Science Invention. 2(1): 12-17.

Anibijuwon, I. I., Oladejo, B. O., Adetitun, D. O. and Kolawole, O. M. (2012). Antimicrobial Activities of Vernonia amygdalina against Oral Microbes. Global Journal of Pharmacology. 6(3): 178-185.

Ankit Saneja, Chetan Sharma, K.R. and Aneja, R. P. (2010). Bitterleaf as Local Substitute for Hops in the Nigerian Brewing Industry. Pharmacia. 2(2): 208-220.

Asante, D.-B., Effah-Yeboah, E., Barnes, P., Abban, H. A., Ameyaw, E. O., Boampong, J. N. and Dadzie, J. B. (2016). Antidiabetic Effect of Young and Old Ethanolic Leaf Extracts of Vernonia amygdalina: A Comparative Study. Journal of Diabetes Research. 1-13.

Atangwho, I. J., Egbung, G. E., Ahmad, M., Yam, M. F. and Asmawi, M. Z. (2013). Antioxidant versus Anti-diabetic Properties of Leaves from Vernonia amygdalina Del. growing in Malaysia. Food Chemistry. 141(4): 3428-3434.

Atangwho, I. J., Yin, K. B., Umar, M. I., Ahmad, M. and Asmawi, M. Z. (2014). Vernonia amygdalina Simultaneously Suppresses Gluconeogenesis and Potentiates Glucose Oxidation via the Pentose Phosphate Pathway in Streptozotocin-Induced Diabetic Rats. BMC Complementary and Alternative Medicine. 14(1): 426.

Audu, S. A., Alemika, E. T., Abdulraheem, R. O., Abdulkareem, S. S., Abdulraheem, R. B. and Ilyas, M. (2012). A Study Review of Documented Phytochemistry of Vernonia amygdalina (Family Asteraceae) as the Basis for Pharmacologic Activity of Plant Extract. Journal of Natural Sciences Research. 2(7): 1-9.

Ayoola, G., Coker, H., Adesegun, S., Adepoju-Bello, A., Obaweya, K., Ezennia, E. and Atangbayila, T. (2008). Phytochemical Screening and Antioxidant Activities of Some Selected Medicinal Plants Used for Malaria Therapy in Southwestern Nigeria. Tropical Journal of Pharmaceutical Research. 7(3): 1019-1024.

Barrero, A. F., Oltra, J. E., Álvarez, M., Raslan, D. S., Saúde, D. A. and Akssira, M. (2000). New sources and antifungal activity of sesquiterpene lactones. Fitoterapia. 71: 60-64.

Egharevba, C., Osayemwenre, E., Imieje, V., Ahomafor, J., Akunyuli, C., Udu-Cosi, A. A., Theophilus, O., James, O., Ali, I. and Falodun, A. (2014). Significance of Bitter Leaf (Vernonia amgdalina) In Tropical Diseases and Beyond: A Review. Malaria Chemotherapy Control and Elimination. 3(1): $1-10$.

Ejike, C. E. C. C., Awazie, S. O., Nwangozi, P. A. and Godwin, C. D. (2013). Synergistic postprandial Blood Glucose Modulatory Properties of Vernonia amygdalina (Del.), Gongronema latifolium (Benth.) and Occimum gratissimum (Linn.) Aqueous Decoctions. Journal of Ethnopharmacology. 149(1): 111-116.

Erasto, P., Grierson, D. S. and Afolayan, A. J. (2006). Bioactive Sesquiterpene Lactones from the Leaves of Vernonia amygdalina. Journal of Ethnopharmacology. 106: 117-120.

Erasto, P., Grierson, D. S. and Afolayan, A. J. (2007). Evaluation of Antioxidant Activity and the Fatty Acid Profile of the Leaves of Vernonia amygdalina Growing in South Africa. Food Chemistry. 104: 636-642.

Eyong, E. U., Agiang, M. A., Atangwho, I. J., Iwara, I. A., Odey, M. O. and Ebong, P. E. (2011). Phytochemicals and Micronutrients Composition of Root and Stem Bark Extracts of Vernonia amygdalina Del. Journal of Medicine and Medical Science. 2(6): 900-903.

Ezeadila, J. O., Nwande, M. O., Ogu, G. I., Aneke, F. A. and Ezeadila, J. O. (2015). Antibacterial Activity of Ethyl Acetate And n-Hexane Extracts of Vernonia amygdalina and Moringa oleifera Leaves on Staphylococcus aureus and Escherichia coli Isolated from Urine Samples. Pelagia Research Library. 6(11): 23-28.

Farombi, E. O. and Owoeye, O. (2011). Antioxidative and Chemopreventive Properties of Vernonia amygdalina and Garcinia biflavonoid. International Journal of Environmental Research and Public Health. 8: 2533-2555.

Ganfon, H., Gbaguidi, F., Frederich, M., Moudachirou, M. and Quetin-Leclercq, J. (2008). In Vitro Evaluation of Antiplasmodial Activity of Plant Samples used in Traditional Medicine in Benin. Planta Medica. 74(9): 1140. 
Georgewill, O.A. and Georgewill, U. O. (2010). Evaluation of the Anti-inflammatory Activity of Extract of Vernonia amygdalina. Asian Pacific Journal of Tropical Medicine. 150-151.

Ghamba, P., Balla, H., Goje, L., Halidu, A. and Dauda, M. (2014). In Vitro Antimicrobial Activities of Vernonia amygdalina on Selected Clinical Isolates. International Journal of Current Microbiology and Applied Sciences. 3(4): 1103-1113.

Gresham, L. J., Ross, J. and Izevbigie, E. B. (2008). Vernonia amygdalina: Anticancer Activity, Authentication, and Adulteration Detection. International Journal of Environmental Research and Public Health. 5(5): 342-348.

Huffman, M. A., Gotoh, S., Izutsu, D., Koshimizu, K. and Kalunde, M. S. (1993). Further Observations on the Use of the Medicinal Plant, Vernonia amygdalina (Del.) by a Wild Chimpanzee, its Possible Effect on Parasite Load, and its Phytochemistry. African Study Monographs. 14(4): 227-240.

Igile, G. O., Wieslaw, O., Jurzysta, M., Stanislaw, B. and Fasanmade, A. (1994). Flavonoids from Vernonia amygdalina and their Antioxidant Activities. Journal of Agricultural and Food Chemistry. 42: 2445-2448.

Ijeh, I. I. and Ejike, C. E. C. C. (2011). Current Perspectives on the Medicinal Potentials of Vernonia amygdalina Del. Journal of Medicinal Plants Research. 5(7): 1051-1061.

Ilondu, E. M. (2010). Phytochemical Composition and Efficacy of Ethanolic Leaf Extracts of Some Vernonia Species against Two Phytopathogenic Fungi. Journal of Biopesticides. 6(2): 165-172.

Imaga, N. O. A. and Bamigbetan, D. O. (2013). In vivo Biochemical Assessment of Aqueous Extracts of Vernonia amygdalina (Bitter leaf). International Journal of Nutrition and Metabolism. 5: 22-27.

Iwalokun, B. A. (2008). Enhanced Antimalarial Effects of Chloroquine by Aqueous Vernonia amygdalina Leaf Extract in Mice Infected with Chloroquine Resistant and Sensitive Plasmodium berghei Strains. African Health Sciences. 8(1): 25-35.

Iwalokun, B. A., Efedede, B. U., Alabi-Sofunde, J. A., Oduala, T., Magbagbeola, O. A. and Akinwande, A. I. (2006). Hepatoprotective and Antioxidant Activities of Vernonia amygdalina on Acetaminophen-induced Hepatic Damage in Mice. Journal of Medicinal Food. 9(4): 524-30.

Jan Mohamed, H. J., Yap, R. W., Loy, S. L., Norris, S. A. and Biesma, R, A. -H. J. (2015). Prevalence and Determinants of Overweight, Obesity, and Type 2 Diabetes mellitus in Adults in Malaysia. Asia Pacific Journal Public Health. 27(2): 123-135.

Jisaka, M., Ohigashi, H., Takegawa, K., Huffman, M. A. and Koshimizu, K. (1993). Antitumoral and Antimicrobial Activities of Bitter Sesquiterpene Lactones of Vernonia amygdalina, a Possible Medicinal Plant Used by Wild Chimpanzees. Bioscience, Biotechnology, and Biochemistry. 57(5): 833-834.

Justin, I., Ekong, P., Ubana, E., Zaini, M. and Ahmad, M. (2012). Synergistic Antidiabetic Activity of Vernonia amygdalina and Azadirachta indica: Biochemical Effects and Possible Mechanism. Journal of Ethnopharmacology. 141(3): 878-887.

Khalafalla, M. M., Abdellatef, E., Daffalla, H. M., Nassrallah, A. A., Lightfoot, D. A., Cocchetto, A. and El-shemy, H. A. (2009). Antileukemia Activity from Root Cultures of Vernonia amygdalina. Journal of Medicinal Plants Research. 3(8): 556-562.

Kiplimo, J. J., Koorbanally, N. A. and Chenia, H. (2011). Triterpenoids from Vernonia auriculifera Hiern Exhibit Antimicrobial Activity. African Journal of Pharmacy and Pharmacolog. 5(8): 1150-1156.

Letchuman, G. R., Nazaimoon, W. M. W., Mohamad, W. B. W., Chandran, L. R., Tee, G. H., Jamaiyah, H. and Faudzi, Y. A. (2010). Prevalence of Diabetes in the Malaysian National Health Morbidity Survey III 2006. Medical Journal of Malaysia. 65(3): 173-179.

Luo, X., Jiang, Y., Fronczek, F. R., Lin, C., Izevbigie, E. B., Lee, S. and Lee, K. S. (2017). Isolation and Structure Determination of a Sesquiterpene Lactone (Vernodalinol) from Vernonia amygdalina Extracts. Pharmaceutical Biology. 49(5): 464-470.

Mansurah, A. A., Kassim, I., Kenpia, B. and Hope, B. B. (2013). Effect of Combined Use of Ocimum gratissimum and Vernonia amygdalina Extract on the Activity of Angiotensin Converting Enzyme, Hypolipidemic and Antioxidant Parameters in Streptozotocininduced Diabetic Rats. African Journal of Biochemistry Research. 7(9): 165-173.

Momoh, M. ., Adikwu, M. and Oyi, A. (2010). Vernonia amydalina Extract and CD4+ Cell counts: An Immune Study. Global Journal of Biotechnology and Biochemistry. 5(2):92-96.

Ngatu, N. R., Okajima, M. K., Yokogawa, M., Hirota, R., Takaishi, M., Eitoku, M. and Suganuma, N. (2012). Anti-Allergic Effects of Vernonia amygdalina Leaf Extracts in Hapten-Induced Atopic Dermatitis-Like Disease in Mice. Allergology International. 61(4): 597-607.

Njan, A. A., Adzu, B., Agaba, A. G., Byarugaba, D., Díaz-Llera, S. and Bangsberg, D. R. (2008). The Analgesic and Antiplasmodial Activities and Toxicology of Vernonia amygdalina. Journal of Medicinal Food. 11(3): 574-81. 
Nwanjo, H. U. (2005). Efficacy of Aqueous Leaf Extract of Vernonia amygdalina on Plasma Lipoprotein and Oxidative Status in Diabetic Rat Models. Nigerian Journal of Physiological Sciences: Official Publication of the Physiological Society of Nigeria. 20(1-2): 39-42.

Nwaoguikpe, R. N. (2010). The Effect of Extract of Bitter Leaf (Vernonia amygdalina) on Blood Glucose Levels Of Diabetic Rats. International Journal of Biology and Chemical Sciences. 4: 721-729.

Oduah, I. (2012). Numerous Uses of Bitter Leaf.

Oguwike, F. N., Offor, C. C. and Onubeze D. P. M. and Nwadioha, A. N. (2013). Evaluation of Activities of Bitterleaf (Vernonia amygdalina) Extract on Haemostatic and Biochemical Profile of Induced Male Diabetic Albino Rats. Journal of Dental and Medical Sciences. 11(2): 60-64.

Opata, M. M. and Izevbigie, E. B. (2006). Aqueous Vernomia amygdalina Extracts Alter MCF-7 Cell Membrane Permeability and Efflux. International Journal of Environmental Research and Public Health. 3(2): 174-179.

Osinubi, A. A. A. (2008). Effects of Vernonia amygdalina and Chlorpropamide on Blood Sugar. Medical Journal of Islamic World Academy of Sciences. 16(3): 115-119.

Owen, O. J., Amakiri, A. O. and Karibi-Botoye, T. A. (2011). Sugar-Lowering Effects of Bitter Leaf (Vernonia amygdalina) in Experimental Broiler Finisher Chickens. Asian Journal of Pharmaceutical and Clinical Research. 4(1): 19-21.

Owoeye, O., Yousuf, S., Akhtar, M. N., Qamar, K., Dar, A., Farombi, E. O. and Choudhary, M. I. (2010). Another Anticancer Elemanolide from Vernonia amygdalina Del. International Journal of Biology and Chemical Sciences. 4: 226-234.

Owu, D. U., Ben, E. E., Antai, A. B., Ekpe, E. A. and Udia, P. M. (2008). Stimulation of Gastric Acid Secretion and Intestinal Motility by Vernonia amygdalina Extract. Fitoterapia. 79(2): 97-100.

Quasie, O., Zhang, Y., Zhang, H., Luo, J. and Kong, L. (2016). Four New Steroid Saponins with Highly Oxidized Side Chains from the Leaves of Vernonia amygdalina. Phytochemistry Letters. 15: 1620 .

Sha, A. (2011). In Vitro Antimalarial Activity of the Extracts of Vernonia amygdalina Commonly Used in Traditional Medicine in Nigeria. Science World Journal. 6(2): 5-9.

Shashank, K. and Abhay, K. (2013). Chemistry and Biological Activities of Flavonoids: An Overview. The Scientific World Journal. 4(2): 32-48.

Toyang, N. J. and Verpoorte, R. (2013). A Review of the Medicinal Potentials of Plants of the Genus Vernonia (Asteraceae). Journal of Ethnopharmacology. 146(3): 681-723.

Udochukwu, U., Omeje, F. I., Uloma, I. S. and Oseiwe, F. D. (2015). Phytochemical Analysis of Vernonia amygdalina and Ocimum gratissimum Extracts and their Antibacterial Activity on Some Drug Resistant Bacteria. American Journal of Research Communication. 3(5): 225-235.

Wedge, D. E., Galindo, J. C. G. and Macõâ, F. A. (2000). Fungicidal Activity of Natural and Synthetic Sesquiterpene Lactone Analogs. Phytochemistry. 53: 747-757.

Wong, F. C., Woo, C. C., Hsu, A. and Tan, B. K. H. (2013). The Anti-Cancer Activities of Vernonia amygdalina Extract in Human Breast Cancer Cell Lines Are Mediated through Caspase-Dependent and p53-Independent Pathways. PLOS ONE. 8(10): 1-15.

Yao, L. H., Jiang, Y. M., Shi, J., Tomás-Barberán, F. A., Datta, N., Singanusong, R. and Chen, S. S. (2004). Flavonoids in Food and their Health Benefits. Plant Foods for Human Nutrition (Dordrecht, Netherlands). 59(3): 113-122.

Yeap, S. K., Ho, W. Y., Beh, B. K., Liang, W. S., Ky, H., Hadi, A. and Alitheen, N. B. (2010). Vernonia amygdalina, an Ethnomedical used Green Vegetable with Multiple Bio-activities. Journal of Medicinal Plants Research. 4(25): 2787-2812. 